\title{
BODY HEIGHT ESTIMATION BASED ON PERCUTANEOUS FOOT LENGTH AND BREADTH OF JAVANESE FEMALES
}

\author{
Nur Mujaddidah Mochtar ${ }^{1}$, Ari Gunawan ${ }^{2}$, Myrtati Dyah Artaria ${ }^{3}$, Susilowati Andajani ${ }^{4}$ \\ ${ }^{1}$ Department of Anatomic and Histology, Faculty of Medicine, Universitas Muhammadiyah Surabaya, ${ }^{2}$ Department of \\ Anatomic and Histology Faculty of Medicine, Universitas Airlangga, Surabaya, ${ }^{3}$ Department of Anthropology, Faculty \\ of Social and Political Sciences, Universitas Airlangga, Surabaya, ${ }^{4}$ Department of Public Health and Preventive \\ Medicine, Universitas Airlangga, Surabaya.
}

\begin{abstract}
ABSTRAK
Estimasi tinggi badan adalah salah satu parameter penting yang digunakan untuk menetapkan individualitas pada kasus tubuh yang dimutilasi atau menemukan bagian tubuh. Tidak jarang bila dalam kasus mutilasi otoritas kepolisian hanya akan memberi bagian tubuh atau kerangka sisa korban. Tujuan penelitian ini adalah untuk mengetahui rumus estimasi tinggi badan berdasarkan perkutan panjang kaki dan lebar kaki pada wanita Jawa di Universitas Muhammadiyah Surabaya. Jenis desain penelitian adalah penelitian observasional cross-sectional. Sampel adalah siswa perempuan Jawa di Universitas Muhammadiyah Surabaya, yang terpilih sebagai unit sampel. Sampel dalam penelitian ini adalah Dua ratus dua puluh dua orang. Variabel independen dari penelitian ini adalah panjang kaki dan nafas kaki, tergantung variabel tinggi badan. Data dianalisis dengan uji normalitas dengan Kolmogorov Smirnoff $(\alpha>0,05)$, uji korelasi Pearson $(\alpha<0,05)$ dan uji regresi linier $(\alpha<0,05)$ untuk mendapatkan rumus estimasi tinggi badan. Hasil penelitian ini adalah, 1) korelasi yang signifikan antara panjang kaki dan tinggi badan $(r=0,731)$, 2) korelasi yang signifikan antara lebar kaki dan tinggi badan (r-0,323), 3) korelasi yang signifikan antara panjang kaki, Kaki lebar dan tinggi badan $(r=$ $0,732)$, 4) Rumus estimasi tinggi badan berdasarkan panjang kaki adalah 688,435 + 3,745 kaki panjang, 5) Rumus perkiraan tinggi badan berdasarkan luas kaki = $1273.002+2.942$ kaki Luas, dan 6) Rumus perkiraan tinggi badan berdasarkan panjang kaki dan lebar kaki adalah $695.227+3.805$ kaki panjang - 0,229 kaki lega. Sebagai kesimpulan dari penelitian ini adalah rumus estimasi yang diperoleh dari tinggi badan berdasarkan panjang kaki dan lebar kaki perempuan Jawa adalah $695.227+3.805$ kaki panjang 0,229 kaki lega. (FMI 2017;53:75-80)
\end{abstract}

Kata kunci: pengukuran, panjang kaki, lebar kaki, tinggi badan, wanita, Jawa

\begin{abstract}
Body height estimation is one of important parameters used for establishing the individuality in cases of mutilated bodies or found body parts. It is not rare that in the cases of mutilation the police authority would only give the body parts or remaining skeletons of the victims. The aims of the study were to find body height estimation formula based on percutaneous of foot length and foot breadth in Javanese females at Surabaya Muhammadiyah University. The type of research design was cross-sectional observational study. Samples were Javanese females student at Muhammadiyah University of Surabaya, which was selected as the sample unit. The samples are in this study was Two-hundred and twenty-two people.The variabel independent of this research are foot length and foot breath, the variabel dependent is body height. Data were analyzed using normality test with Kolmogorov Smirnoff $(\alpha>0,05)$, Pearson correlation test $(\alpha<0,05)$ and linear regression test $(\alpha<0,05)$ to get body height estimation formula. The results of this study is, 1$) A$ significant correlation between foot length and body height $(r=0,731)$, 2) A significant correlation between foot breadth and body height (r-0,323), 3) A significant correlation between foot length, foot breadth and body height $(r=0,732), 4)$ The body height estimation formula based on foot length is $688,435+3,745 *$ foot length, 5) The body height estimation formula based on foot breadth is $=1273,002+2,942 *$ foot breadth, and 6) The body height estimation formula based on foot length and foot breadth is 695,227 + $3,805 *$ foot length $-0,229 *$ foot breadth. As a conclusion of this study is the obtained estimation formula of body height based on foot length and foot breadth of Javanese females is 695,227 + 3,805*foot length - 0,229*foot breadth. (FMI 2017;53:75-80)
\end{abstract}

Keywords: estimation, foot length, foot breadth, body height, females, javenese.

Correspondence: Nur Mujaddidah Mochtar, Department of Anatomic and Histology, Faculty of Medicine, Universitas Muhammadiyah Surabaya

\section{INTRODUCTION}

The height estimate is one of the essential parameters for determining each individual member of the body or one of the mutilated parts so as to have significant value in forensic identification analysis. Research on height estimation, nutritional differences and physical activity may cause variation in a population. Many studies of height estimation focus on upper extremities and lower extremities. Among them are few studies focused on the 
hands and feet to estimate height (Ozaslan et al., 2012). Estimation of this height requires anatomical, mathematical and statistical techniques in formulating the formula (Duyar et al., 2003).

Height is the size of the human body while still alive, while the length of the body is the size of a corpse or the patient is lying down. Length or height is one of the important things for identification (Sambeka et al., 2015). Height becomes one of the personal identification criteria that helps in narrowing the process of inquiry and thus provides useful clues in the investigation (Krishan et al., 2007). The first anthropologist Trotter and Glesser made an estimation formulation to estimate the height of the various parts of the human body, which has led many researchers to develop formulas for different populations around the world (Didia et al., 2009).

Estimation of height is one of the basic analyzes of human bones. Estimation of height by using one bone of the extremity is a frequent forensic activity and many estimation formulas have been produced by the researchers (Kate et al., 1976). Narde et al., 2013 study on estimation of height based on length and width of foot in population Nagpur, India with average height 156,28 $\mathrm{cm}$ yield formula of $\mathrm{TB}(\mathrm{P})=53,0+4,26 *$ long palm Right foot $\pm 0.992 \mathrm{~cm}$ with correlation coefficient $(\mathrm{r})=$ 0.9869 . In the Krishan et al., 2011 study on the northern Indian population with an average height of $154.3 \mathrm{~cm}$ yielded a formula of $\mathrm{TB}=69,346+3,663 *$ foot length $\pm 4,568 \mathrm{~cm}$ with correlation coefficient $(\mathrm{R})=0.636$. In the population of Malaysia (Khairulmazidah et al., 2013) with an average of $\mathrm{TB}=156,086$ produced a formula of TB $(\mathrm{P})=86.554+3.115 *$ right foot sole \pm $4.483 \mathrm{~cm}$ with correlation coefficient $(\mathrm{r})=0.645$.

Studies have found that estimates of height based on the length and width of the sole of the foot have a strong correlation with height and provide a better prediction of body height than other measurements (Meena et al., 2013). Previous researchers have formulated specific formulas for height estimation based on the length and width of the foot for their respective populations and they found that one high-estimate estimate formula can not be applied to the entire population of the world (Narde et al., 2013; Meena Et al., 2013; Rani et al., 2011; Kautilya et al., 2013).

Currently no research has been done on the height estimate based on the length and width of the foot in Javanese young adults in Indonesia especially in Surabaya. Based on the description, it is necessary to study the height estimation based on the length and width of the foot in Javanese women in Muhammadiyah University of Surabaya, so that it can produce a height estimation formula based on the length and width of the foot in Javanese women in Muhammadiyah University of Surabaya.

\section{MATERIALS AND METHODS}

This study used Cross Sectional Study Observational Analytical research design, when data collection of height, foot length and width of foot is done in one measurement time. This study was conducted to determine the relationship between the length of the foot and the width of the foot with height and make the estimation of height estimation based on the length of the soles of the feet and the width of the foot in the Javanese women in the University of Muhammadiyah Surabaya. The sample of this research is 222 Javanese female students at Surabaya University of Muhammadiyah aged 18-23 years who are taken as research sample and willing to become respondent which proved by informed consent.

Height is the length of the vertex to the base of the foot, with the head positioned according to the horizontal line of Frankfurt with the eyes looking straight ahead and the body upright (Glinka, et al., 2008). Height is measured by GPM Anthropometer with $1 \mathrm{~mm}$ accuracy tool. This tool is used for long sizes such as height, height of seat, length for body width replacing large curved calipers (Glinka, et al., 2008). In measuring the length of the soles of the feet, the research subjects stood upright and the length of the foot was measured using a sliding caliper consisting of a millimeter scale ruler, as well as two needle stems, one fixed at the point of scale 0 and the other shifted (Glinka, et al. , 2008). The length of the sole of the foot is measured from the tip of the back of the heel to the big toe, if the second toe is longer than the big toe, the length of the toe is measured from the back end of the heel to the second finger (Wilianto et al. 2010; Narde et al. 2013). Using a sliding caliper, the width of the sole of the foot is measured by the distance between the tibial metatarsal (located medially on the tip of the metatarsal I) and the metatarsal fibulare (located most laterally on the tip of the $\mathrm{V}$ metatarsal). The width of the sole of the foot is measured in the circumstances of the standing research subject (Narde et al., 2013; Krishan et al., 2011).

Measurement results are recorded, grouped and processed based on research variables. The data were tested for distribution by Kolmogorov-Smirnoff test, if the second distribution of normal data, Pearson correlation test was performed, and if abnormal data distribution was done Spearman correlation test. The height estimation formula was obtained by statistical calculation test with single/multiple linear regression. The 
general equation for single (univariate) linear regression is $\mathrm{Y}=\mathrm{a}+\mathrm{b} \mathrm{x} \pm \operatorname{SEE}$ (Krishan et al., 2011). $\mathrm{Y}=$ dependent variable (estimate of height), $\mathrm{a}=$ constant, $\mathrm{b}$ $=$ regression coefficient of independent variable, $\mathrm{x}=$ individual variable/foot measurement, $\mathrm{SEE}=$ Standard Error Estimation.

The height estimate is the result obtained from the regression formula that estimates the height (Y) based on certain independent variables. In this study, height is dependent vaiabel (Y), the length of the sole of the foot and the width of the sole of the foot is the independent variable (x). The results of linear regression analysis will be incorporated into formulas in order to formulate body estimates (Krishan et al., 2011).

\section{RESULTS}

The mean height of Javanese women is $1535,38 \mathrm{~mm}$ with standard deviation $\pm 47,684$. The average length of the foot of ethnic Javanese women measured was $226.15 \mathrm{~mm}$ with standard deviation $\pm 9,312$. The average width of the foot of ethnic Javanese women measured was $89.17 \mathrm{~mm}$ with standard deviation \pm 5,235 . Based on normality test, all data are normally distributed $(p>0,05)$. Pearson correlation test for foot length with height showed strong correlation between kai palm length and height in 222 samples with correlation coefficient $(r)=0,731$.

The height estimation formula based on the foot length (mm) can be formulated based on the result of analysis in Table 2 that is: TB $=688,435+3,745 *$ Long Foot Feet. Pearson correlation test results for the width of the foot with height showed a weak correlation between the width of the foot with height in 222 samples with correlation coefficient $(r)=0.323$.

Table 1. Relationship of the length of the foot with height

\begin{tabular}{lcc}
\hline \multicolumn{1}{c}{ Estimation } & $\begin{array}{c}\text { Pearson correlation } \\
(\mathrm{r})\end{array}$ & $\mathrm{p}$ \\
\hline $\begin{array}{l}\text { Foot length } \\
\text { with body }\end{array}$ & 0.731 & $<0.00$ \\
weight & & 1 \\
\hline
\end{tabular}

Table 2. Results of linear regression analysis for foot length with height (in mm)

\begin{tabular}{cc}
\hline Scores & Results \\
\hline Intercept & 688.435 \\
Slope & 3.745 \\
r square & 0.535 \\
\hline
\end{tabular}

Table 3. Relationship width of the foot with height

\begin{tabular}{lcc}
\hline Estimation & $\begin{array}{c}\text { Pearson } \\
\text { correlation } \\
(\mathrm{r})\end{array}$ & $\mathrm{P}$ \\
\hline $\begin{array}{l}\text { Foot breadth } \\
\text { with body } \\
\text { weight }\end{array}$ & 0.323 & $<0.001$ \\
\hline
\end{tabular}

Table 4. Results of linear regression analysis for height (in $\mathrm{mm}$ ) based on foot width

\begin{tabular}{cc}
\hline Scores & Results \\
\hline Intercept & 1273.002 \\
Slope & 2.942 \\
r square & 0.104 \\
\hline
\end{tabular}

Table 5. Relationship of the length and width of the foot with height

\begin{tabular}{lcc}
\hline \multicolumn{1}{c}{ Estimation } & $\begin{array}{c}\text { Linear correlation } \\
\text { coeffisient }(\mathrm{r})\end{array}$ & SEE \\
\hline $\begin{array}{l}\text { Foot length and } \\
\text { breadth with body } \\
\text { weight }\end{array}$ & 0.732 & 32.651 \\
\hline
\end{tabular}

Table 6. Results of linear regression analysis for height (in $\mathrm{mm}$ ) based on length and width of the foot

\begin{tabular}{cc}
\hline Scores & Results \\
\hline Intercept & 695.227 \\
Slope a & 3.805 \\
Slope b & -0.229 \\
r square & 0.535 \\
\hline
\end{tabular}

The height estimation formula based on the width of the foot $(\mathrm{mm})$ can be formulated based on the results of the analysis in Table 4, ie: TB $=1273,002+2,942 *$ Wide Foot width. The result of linear correlation test for the length and width of the foot with height indicates a strong correlation between the length and width of the foot with height in 222 samples with correlation coefficient $(r)=0.732$. The height estimation formula based on the length and width of the sole of the foot (mm) can be formulated based on Table 6 , ie: $\mathrm{TB}=$ $695,227+3,805 *$ Legs Foot $-0.229 *$ Width of Foot

\section{DISCUSSION}

This study shows that the average height of adult female of ethnic Javanese is $1535,38 \mathrm{~mm}$ with SD 47,684. This result is lower than previous studies in various parts of the world. In the study in Malaysia found that the 
average height in women $156,086 \mathrm{~cm}$ with SD 5,835 (Khairulmazidah et al., 2013), In the study of mongoloid race in Indonesia found that the average height of women is $155.4 \mathrm{~cm}$ with SD 5, 1 (Wilianto et al., 2010), in the same study conducted on mongoloid race in Jogjakarta obtained height average $160,365 \mathrm{~cm}$ with SD 7,722 (Aflanie, 2011). In Indonesia, Javanese highranking trends are not known because there have been no other studies conducted in the same age and ethnic group. The lower average height obtained by researchers in direct comparison with mongoloid race compared to other studies is the sample used by researchers are still young adults where growth is likely to occur.

The occurrence of height differences can be influenced by several factors, including genetic factors, socioeconomic differences, health levels, and great influence by nutrition (Artaria, 2013), prenatal history and postnatal history (Sammalisto, 2008). In addition to genetics, the economic level plays a very important role affecting height, because the economic level affects other factors such as health and education levels and ultimately affects the proportion of a person's body and/or height (Artaria, 2013; Ashizawa et al., 1997; Chuan et Al., 2010).

This study shows that the average length of the foot of ethnic women of ethnic Javanese studied is $226,15 \mathrm{~mm}$ with SD 9,312. The average length of the sole foot is shorter than the average length of the foot of a female Nagpur 24, $324 \mathrm{~cm}$ with SD 1,431 (Narde et al., 2013), New Delhi female $23.60 \mathrm{~cm}$ with SD 1.06 (Meena et al., 2013) , Middle Indian women 23,763 cm with SD 1,666 (Mohite et al., 2014), Turkish women $22,886 \mathrm{~cm}$ with SD 10,74 (Ozaslan et al., 2012), Indian Tamil women 23,224 cm with SD 1,916 (Moorthy et al. , 2014), Gujarati women 23,688 cm with SD 1,4365 (Patel et al., 2011), Sri Lankan women $24.16 \mathrm{~cm}$ with SD 1,063 (Malik et al., 2015) but higher than the average length of Malaysian women's foot $20.08 \mathrm{~cm}$ with SD 1.0 (Hairunnisa et al., 2014), South Indian women 22.56 with SD 11,0285 (Kautilya et al., 2013).

Result of Pearson correlation test between foot length and height showed significant correlation between foot length and height with strong relation $(r=0,731)$ with significant $\mathrm{p}$ value $(\mathrm{p}<0,001)$. The results of this correlation test are higher when compared with Sri Lanka $(\mathrm{r}=0.719)$ (Malik et al., 2015), Northern India $(\mathrm{r}=$ 0,536) (Kanchan et al., 2010), Malaysia ( $r=0.662)$ (Khairulmazidah Et al., 2013), New Delhi $(r=0.583)$ (Meena et al., 2013).

The result of linear regression analysis between foot length and height was found the coefficient of deter- mination for foot length with height is 0,535 , this result is higher than other research such as North India (r2 = 0,405) (Krishan et al., 2011), Turkey ( $\mathrm{R} 2=0.246$ ) (Ozaslan et al., 2012), Tamil India ( $\mathrm{r} 2=0.318$ ) (Moorthy et al., 2014), but the coefficient of determination of this study is almost equal in young Malaysian adult female $(\mathrm{r} 2=0.546)$ (Hairunnisa Et al., 2014). Furthermore, the height estimation formula based on the foot length is formulated from the results of linear regression analysis.

This study shows that the average width of the foot of ethnic women of Javanese studied is $89,17 \mathrm{~mm}$ with SD 5,235 . The average width of the sole of the foot is shorter than the average width of the female foot of Nagpur 9,398 cm with SD 0,539 (Narde et al., 2013), but higher than the average width of female soles of $86.11 \mathrm{~mm}$ with SD 5.86 (Ozaslan et Al., 2012), South Indian women $8,756 \mathrm{~cm}$ with SD 6,747 (Kautilya et al., 2013).

Result of Pearson correlation test between width of foot with height showed significant correlation between foot width and height with moderate relation strength $(\mathrm{r}=$ $0,323)$ with significant $p$ value $(p<0,001)$. The results of this correlation test were lower when compared with the female Nagpur ( $\mathrm{r}=0.9772$ ) (Narde et al, 2013), New Delhi women $(r=0.379)$ (Meena et al., 2013), but the same as the North Indian women $\mathrm{R}=0.3232$ ) (Krishan et al., 2007).

The result of linear regression analysis found the coefficient of determination for the width of the foot with height is 0.104 . This result is lower than in North Indian women (0.171) (Krishan et al., 2011), South Indian women (0.214) (Kautilya et al., 2013). Result of Pearson correlation test between foot length with height and width of foot with height height in this research found that Pearson correlation coefficient higher at foot length, likewise with coefficient of determination in linear regression analysis to get estimation formula, found that coefficient Determination between the width of the foot with a height lower than between the length of the foot with height. It can be observed that height can be estimated more accurately based on the length of the sole of the foot than on the width of the sole of the foot (Krishan et al., 2011). Age and speed of growth is an important factor in the long-footed relationship with height. In young adulthood, the length of the sole of the foot is naturally correlated with the age factor but, this is influenced by the rate of growth of a person different from each other (Scheuer, 2002 cit. Krishan et al., 2013).

In this study also conducted linear regression analysis to get the height formula based on two measurements at 
once that is the length and width of the foot. The result of analysis for correlation (correlation) between height with the length and width of the sole of the foot found strong strength of relationship $(r=0,732)$. This result is stronger than using one of the measurements. Based on this analysis also found that the length and width of the foot together contributes $53.5 \%$ of the height, while the rest is influenced by other factors. This contribution is almost the same as using the length of the sole of the foot, so the estimated height formula will be more accurate results when using the length and width of the sole of the foot at once rather than using only one variable only. The results also show that the sole length of the foot contributes more to the estimated height than the width of the foot.

\section{CONCLUSION}

Based on the results of research and discussion can be seen that a person's height can be estimated by using the sole of the foot or the width of the foot and also both at once. The length of the sole of the foot has a significant relationship with the height with the strength of the relationship is stronger than between the width of the foot with the height. The width of the sole of the foot has a significant relationship with the height of the body with the strength of moderate relationships. The length and width of the sole of the foot at the same time have a significant relationship with the height and give the value of correlation coefficient greater than when using one variable only. The estimation formula for each is (1) Estimation of height $(\mathrm{Y})=688,435+3,745 *$ Foot length, (2) Estimation of height $(\mathrm{Y})=1273,002+2,942$ * Wide Foot width, and Estimation of height $(\mathrm{Y})=$ $695,227+3,805 *$ Legs Foot $-0.229 *$ Wide Footprint.

\section{REFERENCES}

Aflanie, I., 2011., Perbandingan korelasi penentuan tinggi badan antara metode pengukuran panjang tibia perkutaneus dan panjang telapak kaki. Mutiara Medika Vol 11 no 3:201-206.

Artaria, M.D., 2013. Pengaruh faktor keturunan terhadap proporsi tubuh anak. Jurnal Masyarakat, Kebudayaan dan Politik Vol 26, no.1.

Ashizawa, K., Kumakura C., Kusumoto A. and Narasaki, S., 1997. Relative foot size and shape to general body size in Javanese, Filipinas and Japanese with special reference to habitual footwear types. Ann. Hum. Biol. 24;117-129.

Chuan, T.K., Hartono, M. and Kumar, N., 2010. Anthropometry of the Singaporean and Indonesian populations. International Journal of Industrial Ergonomics Vol. 40(6):757-766.
Didia, B.C., Nduka, E.C., and Adele, O., 2009. Stature estimation formulae for Nigerians. J Forensic Sci 54:20-21.

Duyar, I. pelin, C. and Zagyapan, R., 2006. A new method of stature estimation for forensic anthropological application. Anthropological Science 114:23-27.

Glinka, J., Artaria, M.D. and Koesbardiati, T., 2008. In: Artaria MD, editor. Metode pengukuran manusia. Surabaya: Airlangga University Press. p 3-65.

Kanchan, T., Menezes, R.G., Moudgil, R., Kaur, R., Kotian, M.S. and Garg, R.K., 2010. Stature estimation from foot length using universal regression formula in a North Indian population. Journal of Forensic Sciences.Vol 55. No.1.

Kate, B.R., and Mujumdar, R.D., 1976. Stature estimation from femur and humerus by regression and autometry. Acta Anat 94:311-320.

Kautilya, D. V., Bodkha, P., and Poothanathan, P., 2013. Determination of stature and sex from anthropometry of the foot among South Indians. Int. J. Rev. Life. Sci 3(2) 22-26.

Khairulmazidah, M., Nadiah, A.B.N., and Rumiza, R., 2013. Stature estimation using foot and shoeprint length of Malaysian Population. International Journal of Medical, Health, Biomedical, Bioengineering and Pharmaceutical Engineering Vol 7 no.7.

Krishan, K. and Sharma, A., 2007. Estimation of stature from dimensions of hands and feet in a North Indian Population. Journal of Forensic and Legal Medicine. 14. 327-332.

Krishan, K., Kanchan, T., and Passi, N., 2011. Estimation of stature from the foot and its segments in a sub-adult female population of North India. Journal of Foot and Ankle Research 4:24.

Malik, A.R., Akhter, N., Ali, R., Farrukh, R. and Aziz, K., 2015. A study on estimation of stature from foot length. Professional Medical Journal 22(5):632-639.

Meena, M.C., Singh, J.P., Rani, Y., Sharma, G.K., 2013. Stature estimation from the dimensions of foot in females. Antrocom Online Journal of Anthropology vol. 9. n. 2.

Narde, L. and Dongre, A.P., 2013. Body height estimation based on foot length and foot breadth. J Indian Acad Forensic Med. Vol. 35 No.3.

Ozaslan, A., Karadayi, B., Koluyasin, M.O., Kaya, A., and Afsin, H., 2012. Predictive role of hand and foot dimensions in stature estimation. Rom J Leg Med (20) 41-46.

Rani, M., AKTyagi, Ranga, V.K., and AtulMurari., 2011. Stature estimates from foot dimensions. J Punjab Acad Forensic Med Toxicol 11(1).

Sambeka, C., Tanudjaja, G.N., and Pasiak, T.F., 2015. Hubungan tinggi badan dengan panjang tangan pada mahasiswa fakultas kedokteran Unsrat angkatan 2013. Jurnal e-Biomedik Vol.3, no.1. 
Sammalisto, S. 2008. Search for genetic variants influencing human height. Helsinski: University of Helsinski.
Wilianto, W., and Algozi, A.M., 2010. Perkiraan tinggi badan berdasar panjang telapak kaki pada populasi Mongoloid dewasa di Indonesia. Majalah Kedokteran Forensik Indonesia Vol.12 no.4. 